\title{
Burkholderia terrae sp. nov., isolated from a forest soil
}

\author{
Hee-Chan Yang, Wan-Taek Im, Kwang Kyu Kim, Dong-Shan An \\ and Sung-Taik Lee
}

Correspondence

Sung-Taik Lee

e_stlee@kaist.ac.kr
Department of Biological Sciences, Korea Advanced Institute of Science and Technology, 373-1, Guseong-dong, Yuseong-gu, Daejeon, 305-701, South Korea

A Gram-negative, slightly curved rod-shaped bacterium, designated strain $\mathrm{KMYO2}^{\top}$, was isolated from a forest soil in Daejeon, South Korea. On the basis of 16S rRNA gene sequence similarity, strain $\mathrm{KMYO}^{\top}$ was shown to belong to the family Burkholderiaceae of the Betaproteobacteria, and to be related most closely to Burkholderia hospita LMG $20598^{\top}(98 \cdot 7 \%)$, Burkholderia caribensis LMG $18531^{\top}(98 \cdot 0 \%)$ and Burkholderia phymatum LMG $21445^{\top}(97 \cdot 4 \%)$. Its phylogenetic distance from all recognized species within the genus Burkholderia was less than $97 \%$. Chemotaxonomic data [Q-8 as the major ubiquinone; $\mathrm{C}_{16: 0}, \mathrm{C}_{17: 0}$ cyclo, summed feature $7\left(\mathrm{C}_{18: 1} \omega 7 \mathrm{c} / \omega 9 \mathrm{t} / \omega 12 \mathrm{t}\right)$ and $\mathrm{C}_{15: 0}$ as the major fatty acids] supported the affiliation of strain $\mathrm{KMYO} 2^{\top}$ to the genus Burkholderia. The results of DNA-DNA hybridization experiments and physiological and biochemical tests allowed genotypic and phenotypic differentiation of the strain from recognized Burkholderia species. Therefore, $\mathrm{KMYO2}^{\top}\left(=\mathrm{KCTC}_{12388^{\top}}=\mathrm{NBRC} 100964^{\top}\right)$ represents the type strain of a novel species, for which the name Burkholderia terrae sp. nov. is proposed.
The genus Burkholderia was first described by Yabuuchi et al. (1992), and at the time of writing contains 38 species. These organisms have been isolated from diverse ecological niches, ranging from contaminated soils to the human respiratory tract (Coenye \& Vandamme, 2003). During the characterization of bacteria isolated from a forest soil near the Korea Advanced Institute of Science and Technology (KAIST), strain $\mathrm{KMY02}{ }^{\mathrm{T}}$ was cultivated on $\mathrm{R} 2 \mathrm{~A}$ agar at $30{ }^{\circ} \mathrm{C}$, and was then subjected to a taxonomic investigation. The aim of this study was to determine the taxonomic position of the strain based on phenotypic, genotypic and chemotaxonomic characteristics and 16S rRNA gene sequence analysis. The results provide evidence that strain $\mathrm{KMY} 02^{\mathrm{T}}$ represents a novel species within the genus Burkholderia.

Strain KMY02 ${ }^{\mathrm{T}}$ was isolated from a broad-leaved forest soil collected near KAIST, Daejeon, South Korea. The forest soil was homogenized by using an Ace homogenizer (Nihonseiki Kaisha). The suspension was spread on R2A agar plates

Published online ahead of print on 11 November 2005 as DOI 10.1099/ijs.0.63968-0.

The GenBank/EMBL/DDBJ accession number for the 16S rRNA gene sequence of strain $\mathrm{KMYO2}^{\top}$ is $\mathrm{AB} 201285$.

A transmission electron micrograph of a cell of strain $\mathrm{KMYO}^{\top}$ and a table giving levels of DNA-DNA hybridization between this strain and the type strains of closely related Burkholderia species are available as supplementary material in IJSEM Online.
(Difco) after being serially diluted with $50 \mathrm{mM}$ phosphate buffer $(\mathrm{pH} 7 \cdot 0)$. The plates were incubated at $30^{\circ} \mathrm{C}$ for 2 weeks. Single colonies on the plates were purified by transferring them on to new plates and incubating again under the same conditions. The isolate was routinely cultured on R2A agar at $30^{\circ} \mathrm{C}$ and maintained as a glycerol suspension $(20 \%, \mathrm{w} / \mathrm{v})$ at $-70^{\circ} \mathrm{C}$.

Genomic DNA was extracted using a commercial kit (Solgent), and PCR-mediated amplification of the $16 \mathrm{~S}$ rRNA gene and sequencing of the purified PCR product were carried out according to the methods described by Kim et al. (2005). Full sequences of the 16S rRNA gene were compiled using SeqMan software (DNASTAR). 16S rRNA gene sequences of related taxa were obtained from the GenBank database. Multiple alignments were performed by using the CLUSTAL_X program (Thompson et al., 1997), and gaps were edited in the BIOEDIT program (Hall, 1999). Evolutionary distances were calculated using the Kimura two-parameter model (Kimura, 1983). Phylogenetic trees were constructed by using the neighbour-joining (Saitou \& Nei, 1987) and maximum-parsimony (Fitch, 1972) methods, using the MEGA3 program (Kumar et al., 2004) and with bootstrap values based on 1000 replications (Felsenstein, 1985).

A nearly complete $16 \mathrm{~S}$ rRNA gene sequence of strain KMY02 ${ }^{\mathrm{T}}$ was obtained $(1470 \mathrm{bp})$. Preliminary sequence comparison against $16 \mathrm{~S}$ rRNA gene sequences deposited in 
the GenBank database indicated that the isolate belonged to the family Burkholderiaceae of the Betaproteobacteria. On the basis of 16S rRNA gene sequence similarity, the closest cultured relatives to strain $\mathrm{KMY}^{\mathrm{T}}{ }^{\mathrm{T}}$ were Burkholderia hospita LMG $20598^{\mathrm{T}}(98 \cdot 7 \%)$, Burkholderia caribensis LMG $18531^{\mathrm{T}}(98.0 \%)$ and Burkholderia phymatum LMG $21445^{\mathrm{T}}$ $(97 \cdot 4 \%)$. This relationship between strain $\mathrm{KMYO2}^{\mathrm{T}}$ and other members of the genus Burkholderia was also evident in the phylogenetic tree (Fig. 1). Strain $\mathrm{KMYO2}^{\mathrm{T}}$ and the three type strains above formed a monophyletic clade with a high bootstrap value $(95 \%)$, and this was supported by the neighbour-joining and maximum-parsimony algorithms.

The Gram reaction was performed by using the non-staining method described by Buck (1982). Cell morphology was examined by light microscopy (Nikon) and transmission electron microscopy (Carl Zeiss) after negative staining with $1 \%(\mathrm{w} / \mathrm{v})$ phosphotungstic acid. Catalase and oxidase tests were performed by using the procedures outlined by Cappuccino \& Sherman (2002). Substrate utilization as sole carbon source and several other physiological characteristics were determined with the API 32GN, API 20NE and API ZYM galleries according to the instructions of the manufacturer (bioMérieux). Tests for anaerobic growth were performed in a serum bottle containing R2A broth supplemented with thioglycolate $\left(1 \mathrm{~g} \mathrm{l}^{-1}\right)$ and in which the upper air layer was substituted with nitrogen gas. Nitrate and nitrite reduction tests were performed in serum bottles containing R2A broth supplemented with $\mathrm{KNO}_{3}(10 \mathrm{mM})$ and $\mathrm{NaNO}_{2}(10 \mathrm{mM})$, respectively; reduction was monitored on an ion chromatograph (model 790 personal IC; Metrohm) equipped with a conductivity detector and anion exchange column (Metrosep Anion Supp 4; Metrohm). Nitrogenfixing ability was determined by growth in $50 \mathrm{ml}$ of a nitrogen-free medium (DSMZ medium no. 3 ) contained in a $500 \mathrm{ml}$ Erlenmeyer flask. The primer system PolF-PolR (Poly et al., 2001) was used to amplify the nifH gene according to the methods described by Im et al. (2004). Degradation of DNA [using DNA agar (Difco) supplemented with $0.01 \%$ toluidine blue (Merck)], chitin, CM-cellulose, starch (Atlas, 1993), lipid (Kouker \& Jaeger, 1987) and xylan (Ten et al., 2004) was also investigated; reactions were read after 5 days. Growth at different temperatures and $\mathrm{pH}$ was assessed after 5 days incubation. Salt tolerance was tested on R2A medium supplemented with $1-10 \%(w / v) ~ N a C l$ after 5 days incubation. Antibiotic-sensitivity tests were done using filter-paper discs containing the following: streptomycin $\left(5,10\right.$ and $\left.15 \mu \mathrm{g} \mathrm{ml}^{-1}\right)$, tetracycline $(5,10$ and $\left.15 \mu \mathrm{g} \mathrm{ml}^{-1}\right)$, kanamycin $\left(1 \cdot 0,1 \cdot 5\right.$ and $\left.2 \cdot 0 \mathrm{mg} \mathrm{ml}^{-1}\right)$ and ampicillin $\left(20,30\right.$ and $\left.50 \mu \mathrm{g} \mathrm{ml}^{-1}\right)$ (Sigma). Discs were placed on R2A plates spread with KMY02 ${ }^{\mathrm{T}}$ culture and were then incubated at $30^{\circ} \mathrm{C}$ for 5 days. All the phenotypic tests described above were performed in duplicate.

Cells of strain KMY02 ${ }^{\mathrm{T}}$ were Gram-negative, slightly curved rods, and were motile by means of a single polar flagellum (see Supplementary Fig. S1 in IJSEM Online). Nitrogen fixation determined by growth in nitrogen-free medium and a nifH gene was positive. Physiological characteristics of strain $\mathrm{KMY} 02^{\mathrm{T}}$ are summarized in the species description, and comparison of selective characteristics with those of the type strains of its most closely related species is given in Table 1.

Quinones were extracted from cells grown on a nutrient broth (Difco) and analysed as described by Komagata \& Suzuki (1987) by using reversed-phase HPLC. Cellular fatty acids were analysed in organisms grown on trypticase soy agar (TSA; Difco) for 2 days. The cellular fatty acids were saponified, methylated and extracted according to the protocol of the Sherlock Microbial Identification System

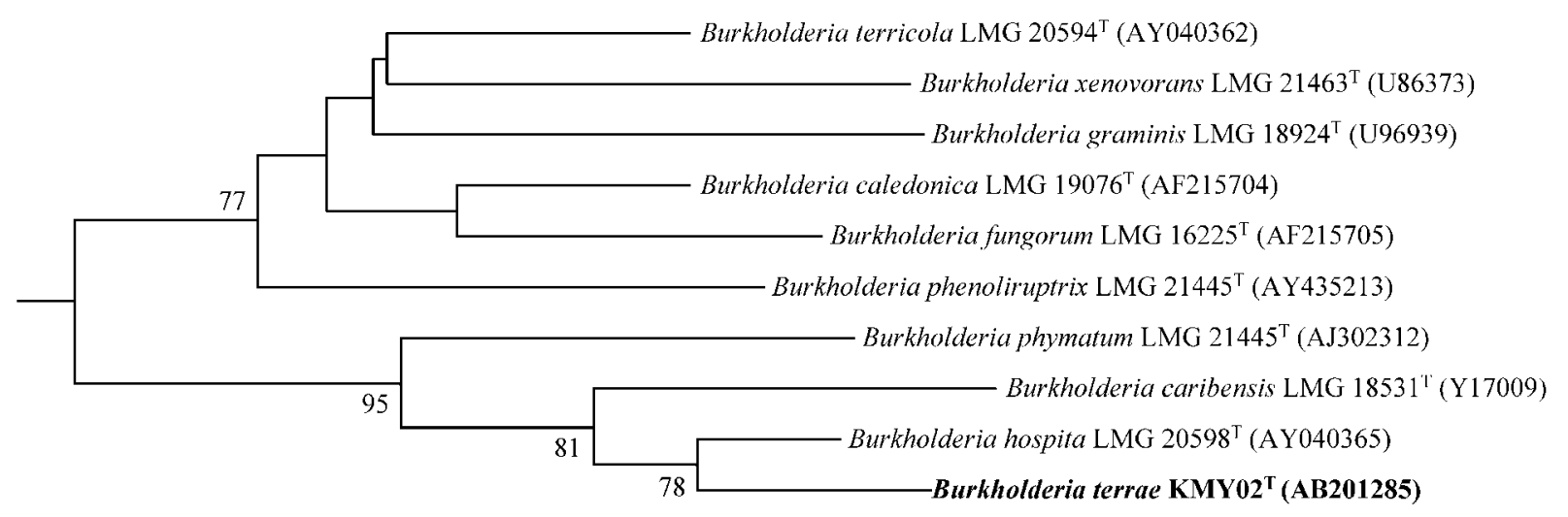

0.005

Fig. 1. Neighbour-joining tree showing the phylogenetic positions of KMYO2 ${ }^{\top}$ and other related taxa based on $16 \mathrm{~S}$ rRNA gene sequences. Bootstrap values (expressed as percentages of 1000 replications) greater than $70 \%$ are shown at branch points. Bar, 0.005 substitutions per nucleotide position. 
Table 1. Differential phenotypic characteristics of strain $\mathrm{KMYO} 2^{\top}$ and phylogenetically closely related Burkholderia species

Strains: 1, KMY02 ${ }^{\mathrm{T}}$; 2, B. hospita LMG $20598^{\mathrm{T}}$; 3, B. phymatum LMG $21445^{\mathrm{T}}$; 4, B. caribensis LMG $18531^{\mathrm{T}}$. +, Positive reaction; - , negative reaction. The following features were present in all strains investigated: motility; growth at $30{ }^{\circ} \mathrm{C}$ and in the presence of $0 \cdot 5-1 \cdot 5 \% \mathrm{NaCl}$; growth on D-glucose, D-gluconate, D-mannose, D-mannitol, D-ribose, D-sorbitol, 3-hydroxybutyrate, inositol, L-alanine, L-arabinose, L-fucose, L-proline, $\mathrm{N}$-acetylglucosamine, phenylacetate and rhamnose; positive for oxidase, alkaline and acid phosphatase, arginine dihydrolase, $\beta$-galactosidase, leucine arylamidase, naphthol-AS-BI-phosphohydrolase and urease. The following features were absent in all strains investigated: growth in the presence of $3 \cdot 0,4.5$ or $6.0 \% \mathrm{NaCl}$; production of indole; nitrite reduction; acidification of D-glucose; hydrolysis of aesculin; assimilation of acetate, adipate, citrate, D-melibiose, 4-hydroxybenzoate, glycogen, malonate, maltose, salicin, amylase, chitinase, cellulase, DNase, protease, xylanase, valine arylamidase, cystine arylamidase, lipase C14, trypsin, $\alpha$-chymotrypsin, $\alpha$-galactosidase, $\alpha$-glucosidase, $\beta$-glucosidase, $\quad \beta$-glucuronidase, $\quad N$-acetyl- $\beta$-glucosaminidase, $\alpha$-mannosidase and $\alpha$-fucosidase.

\begin{tabular}{|c|c|c|c|c|}
\hline Characteristic & 1 & 2 & 3 & 4 \\
\hline Nitrate reduction & - & + & - & + \\
\hline Catalase & + & + & - & + \\
\hline Growth at $42^{\circ} \mathrm{C}$ & - & + & - & - \\
\hline \multicolumn{5}{|l|}{ Antibiotic resistance } \\
\hline Kanamycin $\left(1 \mathrm{mg} \mathrm{ml}^{-1}\right)$ & - & + & - & - \\
\hline Streptomycin $\left(5 \mu \mathrm{g} \mathrm{ml}^{-1}\right)$ & - & + & - & + \\
\hline \multicolumn{5}{|l|}{ Assimilation of: } \\
\hline Caprate & + & + & + & - \\
\hline L-Malate & + & + & + & - \\
\hline Propionate & - & - & - & + \\
\hline Valerate & - & + & + & - \\
\hline Histidine & + & + & + & - \\
\hline 2-Ketogluconate & + & + & + & - \\
\hline Sucrose & - & + & - & - \\
\hline Itaconate & - & - & + & - \\
\hline Suberate & + & - & - & - \\
\hline DL-Lactate & + & - & + & + \\
\hline 5-Ketogluconate & + & - & - & - \\
\hline 3-Hydroxybenzoate & - & - & + & - \\
\hline L-Serine & + & + & + & - \\
\hline \multicolumn{5}{|l|}{ API ZYM results } \\
\hline Esterase (C4) & - & - & - & + \\
\hline Esterase lipase (C8) & + & - & - & - \\
\hline Mean DNA G + C content $(\mathrm{mol} \%)$ & 62 & 62 & 61 & 61 \\
\hline
\end{tabular}

(MIDI). The fatty acids analysed by GC (Hewlett Packard 6890) were identified using the Microbial Identification software package (Sasser, 1990).

Total DNA for determination of the $\mathrm{G}+\mathrm{C}$ content was extracted from cells grown on a nutrient agar plate (Difco) using the method described by Ausubel et al. (1995). RNA in the DNA solution was removed by incubation with a mixture of RNase A and T1 (each at 20 units $\mathrm{ml}^{-1}$ ) at $30^{\circ} \mathrm{C}$ for $1 \mathrm{~h}$. The $\mathrm{G}+\mathrm{C}$ content of the total DNA was analysed as described by Mesbah et al. (1989) using reversedphase HPLC. DNA-DNA hybridization was performed fluorometrically according to the method of Ezaki et al. (1989), using photobiotin-labelled DNA probes and microdilution wells.

Ubiquinone Q-8 was detected as the predominant quinone system in strain $\mathrm{KMY02}{ }^{\mathrm{T}}$; this is also the case in all other species of the genus Burkholderia. The cellular fatty acid profile of strain $\mathrm{KMY}^{\mathrm{T}}{ }^{\mathrm{T}}$ included $\mathrm{C}_{16: 0}(28 \cdot 1 \%), \mathrm{C}_{17: 0}$ cyclo $(23 \cdot 4 \%)$, summed feature $7 \quad\left(\mathrm{C}_{18: 1} \omega 7 \mathrm{c} / \omega 9 t / \omega 12 t\right.$, $11 \cdot 8 \%)$ and $\mathrm{C}_{15: 0}(7 \cdot 5 \%)$. Significant differences were found between strain $\mathrm{KMY}^{\mathrm{T}}{ }^{\mathrm{T}}$ and the other Burkholderia species investigated with regard to the fatty acid profile; the proportion of hydroxyl fatty acids is lower in strain $\mathrm{KMY}^{\mathrm{T}}{ }^{\mathrm{T}}$ and it has $\mathrm{C}_{15: 0}$ as a major component (Table 2).

The DNA G $+\mathrm{C}$ content of strain $\mathrm{KMY}^{\mathrm{T}}{ }^{\mathrm{T}}$ is $62 \mathrm{~mol} \%$, a value similar to those of members of the genus Burkholderia (Table 1). The level of DNA-DNA relatedness between

Table 2. Cellular fatty acid content (\%) of strain $\mathrm{KMYO}^{\top}$ and phylogenetically closely related Burkholderia species

Strains: 1, KMY02 ${ }^{\mathrm{T}}$; 2, B. hospita LMG $20598^{\mathrm{T}}$; 3, B. caribensis LMG $18531^{\mathrm{T}}$; 4 , B. phymatum LMG $21445^{\mathrm{T}}$. Fatty acids that account for less than $0.5 \%$ of the total are not shown.

\begin{tabular}{|c|c|c|c|c|}
\hline Fatty acid & 1 & 2 & 3 & 4 \\
\hline \multicolumn{5}{|l|}{ Saturated } \\
\hline $\mathrm{C}_{12: 0}$ & $3 \cdot 0$ & & & $1 \cdot 7$ \\
\hline $\mathrm{C}_{14: 0}$ & $4 \cdot 7$ & $4 \cdot 8$ & $5 \cdot 9$ & $3 \cdot 7$ \\
\hline $\mathrm{C}_{15: 0}$ & $7 \cdot 5$ & & & \\
\hline $\mathrm{C}_{16: 0}$ & $28 \cdot 1$ & $18 \cdot 5$ & $16 \cdot 0$ & $18 \cdot 4$ \\
\hline $\mathrm{C}_{17: 0}$ & $1 \cdot 8$ & & & \\
\hline $\mathrm{C}_{18: 0}$ & $1 \cdot 5$ & & & \\
\hline \multicolumn{5}{|l|}{ Branched } \\
\hline iso- $\mathrm{C}_{17: 0} 3-\mathrm{OH}$ & & & $1 \cdot 2$ & \\
\hline \multicolumn{5}{|l|}{ Hydroxy } \\
\hline $\mathrm{C}_{14: 0} 2-\mathrm{OH}$ & $1 \cdot 6$ & & & \\
\hline $\mathrm{C}_{16: 0} 2-\mathrm{OH}$ & & $1 \cdot 8$ & $5 \cdot 6$ & $3 \cdot 2$ \\
\hline $\mathrm{C}_{16: 1} 2-\mathrm{OH}$ & & $1 \cdot 5$ & $2 \cdot 9$ & $5 \cdot 8$ \\
\hline $\mathrm{C}_{16: 0} 3-\mathrm{OH}$ & & $4 \cdot 8$ & $8 \cdot 9$ & $4 \cdot 8$ \\
\hline $\mathrm{C}_{18: 1} 2-\mathrm{OH}$ & & & $1 \cdot 2$ & \\
\hline \multicolumn{5}{|l|}{ Cyclo } \\
\hline $\mathrm{C}_{17: 0}$ cyclo & $23 \cdot 4$ & $10 \cdot 4$ & $24 \cdot 9$ & $23 \cdot 7$ \\
\hline $\mathrm{C}_{19: 0}$ cyclo $\omega 8 c$ & $6 \cdot 3$ & $3 \cdot 5$ & $15 \cdot 1$ & $7 \cdot 0$ \\
\hline \multicolumn{5}{|l|}{ Summed features ${ }^{\star}$} \\
\hline 2: $\mathrm{C}_{14: 0} 3-\mathrm{OH} /$ iso- $\mathrm{C}_{16: 1} \mathrm{I}$ & $6 \cdot 7$ & $6 \cdot 9$ & $11 \cdot 7$ & $5 \cdot 1$ \\
\hline 3: $\mathrm{C}_{16: 1} \omega 7 c /$ iso- $\mathrm{C}_{15: 0} 2-\mathrm{OH}$ & $3 \cdot 3$ & $17 \cdot 8$ & $2 \cdot 3$ & $7 \cdot 2$ \\
\hline $7: \mathrm{C}_{18: 1} \omega 7 c / \omega 9 t / \omega 12 t$ & $11 \cdot 8$ & $30 \cdot 0$ & $4 \cdot 2$ & $19 \cdot 4$ \\
\hline
\end{tabular}

${ }^{\star}$ Summed features are groups of two or three fatty acids that cannot be separated by GLC with the MIDI system. 
strain $\mathrm{KMY}^{\mathrm{T}} 2^{\mathrm{T}}$ and the type strains of B. hospita, B. caribensis and B. phymatum was 28,36 and $22 \%$, respectively (see Supplementary Table S1 in IJSEM Online). Levels of DNA-DNA hybridization were determined to be less than $70 \%$, which is the threshold used to delineate a genomic species (Stackebrandt \& Goebel, 1994). The results therefore support the designation of strain $\mathrm{KMY} 02^{\mathrm{T}}$ as representing a separate, previously unrecognized species.

On the basis of its morphological, physiological and chemotaxonomic characteristics, together with data from $16 \mathrm{~S}$ rRNA gene sequence comparisons, strain $\mathrm{KMY02}^{\mathrm{T}}$ should be placed in the genus Burkholderia as a novel species, for which the name Burkholderia terrae sp. nov. is proposed.

\section{Description of Burkholderia terrae sp. nov.}

Burkholderia terrae (ter'rae. L. gen. n. terrae of the earth).

Cells are Gram-negative, slightly curved rods, $1 \cdot 6-2 \cdot 0 \mu \mathrm{m}$ long by $0 \cdot 6-0 \cdot 8 \mu \mathrm{m}$ wide, motile by means of a single polar flagellum. Colonies grown on R2A are circular, convex and cream-coloured. Temperature range for growth is $25-30{ }^{\circ} \mathrm{C}$; no growth occurs at $42{ }^{\circ} \mathrm{C}$. Growth occurs in the absence of $\mathrm{NaCl}$ and in the presence of $1.5 \%(\mathrm{w} / \mathrm{v}) \mathrm{NaCl}$, but not above $3.0 \%(\mathrm{w} / \mathrm{v}) \mathrm{NaCl}$. Nitrate is not reduced. Nitrogen fixation is positive. Catalase, oxidase, arginine dihydrolase, urease and $\beta$-galactosidase activities are positive. Tryptophanase and $\beta$-glucosidase activities are negative. Positive for assimilation of mannose, gluconate, caprate, phenylacetate, mannitol, D-glucose, L-fucose, D-sorbitol, L-arabinose, malate, histidine, 2-ketogluconate, 3-hydroxybutyrate, L-proline, rhamnose, $\mathrm{N}$-acetylglucosamine, D-ribose, inositol, suberate, DL-lactate, L-alanine, 5-ketogluconate and L-serine. Negative for assimilation of adipate propionate, valerate, sucrose, itaconate and 3-hydroxybenzonate. Positive for alkaline phosphatase, esterase lipase $\mathrm{C} 8$, leucine arylamidase, acid phosphatase and naphthol-AS-BI-phosphohydrolase; negative for esterase $\mathrm{C} 4$, lipase $\mathrm{C} 14$, valine arylamidase, cystine arylamidase, trypsin, $\alpha$-chymotrypsin, $\alpha$-galactosidase, $\beta$-galactosidase, $\beta$-glucuronidase, $\alpha$ glucosidase, $\beta$-glucosidase, $N$-acetyl- $\beta$-glucosaminidase, $\alpha$ mannosidase and $\alpha$-fucosidase. Resistant to $20 \mu \mathrm{g}$ ampicillin $\mathrm{ml}^{-1}$ and $5 \mu \mathrm{g}$ tetracycline $\mathrm{ml}^{-1}$ but susceptible to $1 \mathrm{mg}$ kanamycin $\mathrm{ml}^{-1}$ and $5 \mu \mathrm{g}$ streptomycin $\mathrm{ml}^{-1}$. Predominant ubiquinone is Q-8. The major fatty acids are $\mathrm{C}_{16: 0}, \mathrm{C}_{17: 0}$ cyclo, summed feature $7\left(\mathrm{C}_{18: 1} \omega 7 \mathrm{c} / \omega 9 t / \omega 12 t\right)$ and $\mathrm{C}_{15: 0}$. The $\mathrm{G}+\mathrm{C}$ content of the genomic DNA is $62 \mathrm{~mol} \%$.

The type strain is $\mathrm{KMYO2}^{\mathrm{T}}\left(=\mathrm{KCTC} 12388^{\mathrm{T}}=\mathrm{NBRC}\right.$ $\left.100964^{\mathrm{T}}\right)$.

\section{Acknowledgements}

This work was supported by the Eco-Technopia-21, Ministry of Environment and the 21C Frontier Microbial Genomics and Application Center Program, Ministry of Science \& Technology (grant MG05-0101-4-0), South Korea.

\section{References}

Atlas, R. M. (1993). Handbook of Microbiological Media. Edited by L. C. Parks. Boca Raton, FL: CRC Press.

Ausubel, F. M., Brent, R., Kingston, R. E., Moore, D. D., Seidman, J. G., Smith, J. A. \& Struhl, K. (editors) (1995). Short Protocols in Molecular Biology: a Compendium of Methods from Current Protocols in Molecular Biology, 3rd edn. New York: Wiley.

Buck, J. D. (1982). Nonstaining (KOH) method for determination of Gram reactions of marine bacteria. Appl Environ Microbiol 44, 992-993.

Cappuccino, J. G. \& Sherman, N. (2002). Microbiology: a Laboratory Manual, 6th edn. Menlo Park, CA: Benjamin Cummings.

Coenye, T. \& Vandamme, P. (2003). Diversity and significance of Burkholderia species occupying diverse ecological niches. Environ Microbiol 5, 719-729.

Ezaki, T., Hashimoto, Y. \& Yabuuchi, E. (1989). Fluorometric deoxyribonucleic acid-deoxyribonucleic acid hybridization in microdilution wells as an alternative to membrane filter hybridization in which radioisotopes are used to determine genetic relatedness among bacterial strains. Int J Syst Bacteriol 39, 224-229.

Felsenstein, J. (1985). Confidence limits on phylogenies: an approach using the bootstrap. Evolution 39, 783-791.

Fitch, W. M. (1972). Toward defining the course of evolution: minimum change for a specific tree topology. Syst Zool 20, 406-416.

Hall, T. A. (1999). BIOEDIT: a user-friendly biological sequence alignment editor and analysis program for Windows 95/98/NT. Nucleic Acids Symp Ser 41, 95-98.

Im, W.-T., Bae, H.-S., Yokota, A. \& Lee, S. T. (2004). Herbaspirillum chlorophenolicum sp. nov., a 4-chlorophenol-degrading bacterium. Int J Syst Evol Microbiol 54, 851-855.

Kim, M. K., Im, W.-T., Ohta, H., Lee, M. \& Lee, S.-T. (2005). Sphingopyxis granuli sp. nov., a $\beta$-glucosidase producing bacterium in the family Sphingomonadaceae in $\alpha-4$ subclass of the Proteobacteria. J Microbiol 43, 111-116.

Kimura, M. (1983). The Neutral Theory of Molecular Evolution. Cambridge: Cambridge University Press.

Komagata, K. \& Suzuki, K. I. (1987). Lipid and cell wall analysis in bacterial systematics. Methods Microbiol 19, 161-207.

Kouker, G. \& Jaeger, K.-E. (1987). Specific and sensitive plate assay for bacterial lipase. Appl Environ Microbiol 53, 211-213.

Kumar, S., Tamura, K. \& Nei, M. (2004). MEGA3: integrated software for Molecular Evolutionary Genetics Analysis and sequence alignment. Brief Bioinform 5, 150-163.

Mesbah, M., Premachandran, U. \& Whitman, W. B. (1989). Precise measurement of the $\mathrm{G}+\mathrm{C}$ content of deoxyribonucleic acid by highperformance liquid chromatography. Int J Syst Bacteriol 39, 159-167.

Poly, F., Monrozier, L. J. \& Bally, R. (2001). Improvement in the RFLP procedure for studying the diversity of nifH genes in communities of nitrogen fixers in soil. Res Microbiol 152, 95-103.

Saitou, N. \& Nei, M. (1987). The neighbor-joining method: a new method for reconstructing phylogenetic trees. Mol Biol Evol 4, 406-425.

Sasser, M. (1990). Identification of Bacteria by Gas Chromatography of Cellular Fatty Acids. MIDI Technical Note 101. Newark, DE: MIDI.

Stackebrandt, E. \& Goebel, B. M. (1994). Taxonomic note: a place for DNA-DNA reassociation and 16S rRNA sequence analysis in the present species definition in bacteriology. Int J Syst Bacteriol 44, 846-849.

Ten, L. N., Im, W.-T., Kim, M.-K., Kang, M.-S. \& Lee, S.-T. (2004). Development of a plate technique for screening of 
polysaccharide-degrading microorganisms by using a mixture of insoluble chromogenic substrates. J Microbiol Methods 56, 375-382.

Thompson, J. D., Gibson, T. J., Plewniak, F., Jeanmougin, F. \&

Higgins, D. G. (1997). The CLUSTAL_X windows interface: flexible strategies for multiple sequence alignment aided by quality analysis tools. Nucleic Acids Res 25, 4876-4882.
Yabuuchi, E., Kosako, Y., Oyaizu, H., Yano, I., Hotta, H., Hashimoto, Y., Ezaki, T. \& Arakawa, M. (1992). Proposal of Burkholderia gen. nov. and transfer of seven species of the genus Pseudomonas homology group II to the new genus, with the type species Burkholderia cepacia (Palleroni and Holmes 1981) comb. nov. Microbiol Immunol 36, 1251-1275. 